\title{
Subfossil Cladocera from surface sediment in thermokarst lakes in northeastern Siberia, Russia, in relation to limnological and climatic variables
}

\author{
Larisa Frolova $\cdot$ Larisa Nazarova $\cdot$ \\ Ludmila Pestryakova $\cdot$ Ulrike Herzschuh
}

Received: 17 December 2012 / Accepted: 6 June 2014/Published online: 13 June 2014

(C) Springer Science+Business Media Dordrecht 2014

\begin{abstract}
Subfossil Cladocera were sampled and examined from the surface sediments of 35 thermokarst lakes along a temperature gradient crossing the tree line in the Anabar-river basin in northwestern Yakutia, northeastern Siberia. The lakes were distributed through three environmental zones: typical tundra, southern tundra and forest tundra. All lakes were situated within the continuous permafrost zone. Our investigation showed that the cladoceran communities in the lakes of the Anabar region are diverse and abundant, as reflected by taxonomic richness, and high diversity and evenness indices $(\mathrm{H}=1.89 \pm$ $0.51 ; \mathrm{I}=0.8 \pm 0.18$ ). CONISS cluster analysis indicated that the cladoceran communities in the three ecological zones (typical tundra, southern tundra and forest-tundra) differed in their taxonomic composition
\end{abstract}

L. Frolova $\cdot$ L. Nazarova $(\bowtie)$

Kazan Federal University, Kremlyovskaya str. 18, 420008 Kazan, Russia

e-mail: larisa.nazarova@awi.de; nazarova_larisa@mail.ru

L. Nazarova $\cdot$ U. Herzschuh

Alfred Wegener Institute, Helmholtz Centre for Polar and

Marine Research - Research Unit Potsdam,

Telegrafenberg A43, 14473 Potsdam, Germany

L. Pestryakova

North-Eastern Federal University, 58 Belinsky Street,

677891 Yakutsk, Russia

U. Herzschuh

University of Potsdam, Am Neuen Palais 10,

14469 Potsdam, Germany and structure. Differences in the cladoceran assemblages were related to limnological features and geographical position, vegetation type, climate and water chemistry. The constrained redundancy analysis indicated that $\mathrm{T}_{\text {July }}$, water depth and both sulphate $\left(\mathrm{SO}_{4}{ }^{2-}\right)$ and silica $\left(\mathrm{Si}^{4+}\right)$ concentrations significantly $(p \leq 0.05)$ explained variance in the cladoceran assemblage. $\mathrm{T}_{\text {July }}$ featured the highest percentage $(17.4 \%)$ of explained variance in the distribution of subfossil Cladocera. One of the most significant changes in the structure of the cladoceran communities in the investigated transect was the replacement of closely related species along the latitudinal and vegetation gradient. The results demonstrate the potential for a regional cladoceran-based temperature model for the Arctic regions of Russia, and for and Yakutia in particular.

Keywords Cladocera - Russian Arctic .

Temperature $\cdot$ Water depth · Palaeolimnology

\section{Introduction}

Thermokarst lakes and ponds are the most common type of Arctic lake (ACIA 2005). These lakes most commonly form as a consequence of thawing of icerich permafrost, which forms depressions that subsequently fill with surface waters (Wetterich et al. 2008). Thermokarst lakes act as "hot spots" of biological 
activity in northern regions with diverse and abundant microbial, plankton, benthic, aquatic plant, fish and bird communities (ACIA 2005). Climate change is emerging as the most far-reaching and significant stressor on Arctic biodiversity (Petersen 2010). Warming climate is expected to change or even reduce the distribution of animals living in Arctic regions.

Cladocera (Crustacea: Branchiopoda) are a key component of aquatic ecosystems; their community structure reflects a combination of the physical, chemical and biological characteristics of the ecosystem they inhabit (Davidson et al. 2007). Their chitinous exoskeletal components (shell, head shield, postabdomen, postabdominal claws, antennal segments and mandibles) are usually well preserved in sediments and most are identifiable to the species level (Korhola and Rautio 2001). Hence, cladoceran subfossils preserved in lake sediments contain valuable information about the climatic and environmental conditions prevailing during the lifetime of those organisms, which allows cladocerans to be used in palaeoecological studies (Korhola et al. 2000; Kienast et al. 2011).

The interpretation of subfossil cladoceran assemblages requires a detailed knowledge about their distribution and ecological preferences. Unfortunately, such information is still fragmentary and often restricted to calibration data sets from limited geographical areas (Lotter et al. 1997; Rautio 1998; Korhola 1999; Swadling et al. 2000; Sweetman et al. 2010). Very little is known about the biological and functional diversity of zooplankton taxa and communities that reside in the remote aquatic ecosystems of Arctic Russia. Scientifically documented knowledge on both the biological and functional diversity of the freshwater fauna in eastern Siberia and Beringia and the role of environmental factors in regulating cladoceran distribution is especially rare (Samchyshyna et al. 2008; Frolova et al. 2013) because of the difficulty accessing lakes in the Siberian Arctic.

Both the open-water and vegetation periods for the majority of aquatic organisms in the Arctic are limited to a short time interval of 1 or 2 months. Samples of zooplankton are usually collected using standard hydrobiological methods at one or two times per season so do not reflect the presence of all species. Therefore, the real species richness of such water bodies remains unknown because of the uncertain seasonal dynamics of their life cycles in Arctic water bodies. The top 0-1 cm of sediment in a shallow lake is typically the accretion of material deposited over approximately 1-5 years depending upon the lake productivity (Anderson and Battarbee 1994). Therefore, palaeolimnological techniques can provide a better understanding of the taxonomic diversity for at least some selected families (Chydoridae, Bosminidae).

The aim of the present investigation was to examine subfossil cladoceran assemblages from northwestern Yakutia (northeastern Siberia, Russia), to document their distribution within the region, and to reveal the influence of environmental variables in structuring the cladoceran communities. To do this, we examined the surface sediments of 35 lakes that spanned a northsouth transect across the modern treeline, and we related the cladoceran assemblages to the physical and chemical characteristics of these lakes.

Study site

The study lakes are located in the catchment area of the Anabar River in the northwestern part of Yakutia (Russia) west of the Lena River (Fig. 1). The river Anabar is situated north of the Arctic Circle, is $939 \mathrm{~km}$ long and has a catchment area of $104,461 \mathrm{~km}^{2}$ (Chistyakov 1964). The climatic conditions of the Anabar region show extreme seasonal variations. Short, cool summers are followed by long and very cold winters. The coldest month is January with an average air temperature below $-34{ }^{\circ} \mathrm{C}$ and the lowest temperatures reaching $-53{ }^{\circ} \mathrm{C}$. The mean July temperatures are $10-12{ }^{\circ} \mathrm{C}$ with maximum summer temperatures of $30-35^{\circ} \mathrm{C}$ (Atlas Arktiki 1985). The mean annual air temperatures are between -10 and $-13{ }^{\circ} \mathrm{C}$ (Gavrilova 1998). Consequently, shallow lakes are frozen to the bottom for $8-9$ months of the year (Wetterich et al. 2008), which limits the annual period of active growth for aquatic organisms, such as Cladocera, in this region.

The mean annual precipitation in the Anabar region is low and varies from 140 to $350 \mathrm{~mm}$. However, this still exceeds evaporation in most places (with $\sim 100 \mathrm{~mm}$ in the north and $\sim 200 \mathrm{~mm}$ in the south) because of the predominance of freezing temperatures for most of the year. Less than $30 \%$ of the precipitation occurs in winter and most occurs during the summer months (Kirilov et al. 2007). The low precipitation in winter results in a shallow snow covering that ranges between 20 and $40 \mathrm{~cm}$ in the 


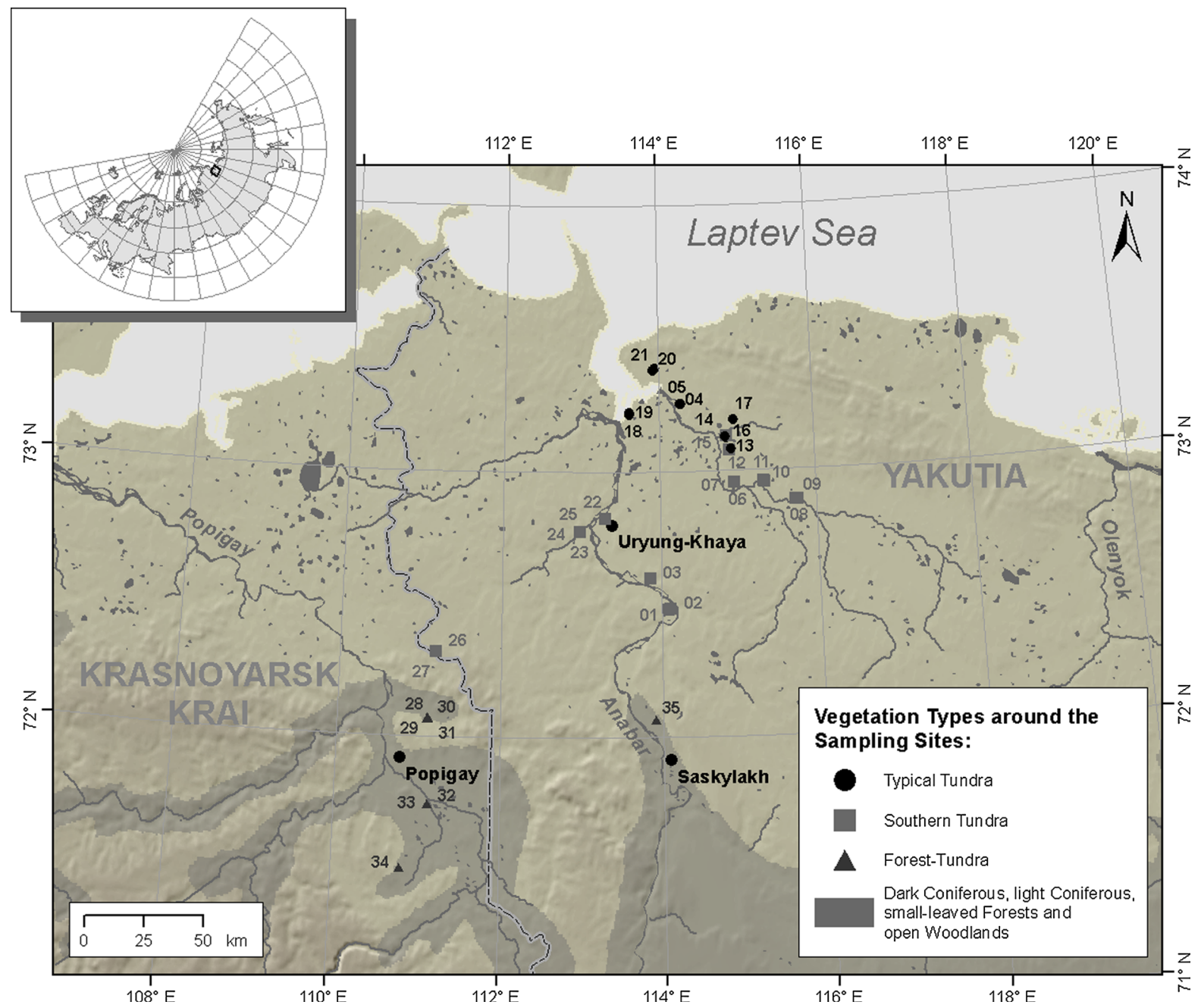

Fig. 1 Map of the study region showing the location of the sampled lakes and types of vegetation

lowlands (Atlas selskogo khozyaistva Yakutskoi 1989). The permafrost table in the region is 400-800 m thick. In summer, the upper $0.5-2.0 \mathrm{~m}$ of the ground is generally unfrozen (Gavrilova 1998). The thawing of the upper permafrost table and the soil-water content above the frozen ground provides the moisture necessary for vegetation. The formation of thawed lakes (Wetterich et al. 2008) is directly connected to permafrost processes such as ice wedge growth, thermokarst and thermoerosion as well as the fluvial dynamics of the Anabar River and its flood plain. These lakes are mostly shallow (1-5 m) and relatively small.

The study region is located within three different vegetation ecozones (typical tundra, southern tundra and forest-tundra). The typical tundra is dominated by grasses, sedges and dwarf shrubs $(<40 \mathrm{~cm}$ tall $)$ such as Vaccinium vitis-idea L., V. uliginosum L. ssp., Ledum palustris L. (1753), Betula nana and small Salix L. taxa. In the southern tundra, the vegetation is dominated by shrub taxa that are often $>40 \mathrm{~cm}$ (e.g., Betula exilis Sukaczev, Salix pulchra Cham., S. lanata L., S. glauca L., Alnus fruticosa Rupr.), dwarf shrubs and mosses (Walker 2000). The forest-tundra zone is characterised by patches of open larch forest (mostly Larix dahurica (Rupr.) Rupr. with the occasional occurrence of Larix sibirica Ledeb. (Karavaev and Skryabin 1971) and pure shrublands comparable to the southern tundra zone but with a higher Alnus component. 
Table 1 Location, elevation and size of the studied lakes

\begin{tabular}{|c|c|c|c|c|}
\hline Lake No. & Latitude $\left({ }^{\circ} \mathrm{N}\right)$ & Longitude $\left({ }^{\circ} \mathrm{E}\right)$ & Elevation (m, a.s.l.) & $\operatorname{Size}^{\mathrm{a}}(\mathrm{m} \times \mathrm{m})$ \\
\hline 07-SA-01 & $72^{\circ} 29^{\prime} 02.5^{\prime \prime}$ & $114^{\circ} 06^{\prime} 12.3^{\prime \prime}$ & 10 & $2,000 \times 1,000$ \\
\hline 07-SA-02 & $72^{\circ} 28^{\prime} 48.1^{\prime \prime}$ & $114^{\circ} 05^{\prime} 5.4^{\prime \prime}$ & 6 & $30 \times 30$ \\
\hline 07-SA-03 & $72^{\circ} 35^{\prime} 60.0^{\prime \prime}$ & $113^{\circ} 51^{\prime} 25.2^{\prime \prime}$ & 6 & $150 \times 100$ \\
\hline 07-SA-04 & $73^{\circ} 15^{\prime} 10.0^{\prime \prime}$ & $114^{\circ} 16^{\prime} 56.9^{\prime \prime}$ & 3 & $500 \times 300$ \\
\hline 07-SA-05 & $73^{\circ} 15^{\prime} 16.7^{\prime \prime}$ & $114^{\circ} 16^{\prime} 19.8^{\prime \prime}$ & 3 & $1,000 \times 1,000$ \\
\hline 07-SA-06 & $72^{\circ} 57^{\prime} 20.4^{\prime \prime}$ & $114^{\circ} 57^{\prime} 28.7^{\prime \prime}$ & 0 & $300 \times 200$ \\
\hline 07-SA-07 & $72^{\circ} 57^{\prime} 20.4^{\prime \prime}$ & $114^{\circ} 57^{\prime} 28.7^{\prime \prime}$ & 0 & $500 \times 500$ \\
\hline 07-SA-08 & $72^{\circ} 53^{\prime} 09.6^{\prime \prime}$ & $115^{\circ} 43^{\prime} 34.3^{\prime \prime}$ & 4 & $2,000 \times 2,000$ \\
\hline 07-SA-09 & $72^{\circ} 53^{\prime} 06.0^{\prime \prime}$ & $115^{\circ} 45^{\prime} 18.0^{\prime \prime}$ & 4 & $100 \times 100$ \\
\hline 07-SA-10 & $72^{\circ} 57^{\prime} 23.1^{\prime \prime}$ & $115^{\circ} 20^{\prime} 16.9^{\prime \prime}$ & 11 & $2,000 \times 2,000$ \\
\hline 07-SA-11 & $72^{\circ} 57^{\prime} 38.4^{\prime \prime}$ & $115^{\circ} 19^{\prime} 50.4^{\prime \prime}$ & 4 & $4,000 \times 300$ \\
\hline 07-SA-12 & $73^{\circ} 04^{\prime} 44.5^{\prime \prime}$ & $114^{\circ} 54^{\prime} 17.8^{\prime \prime}$ & 0 & $2,000 \times 2,000$ \\
\hline 07-SA-13 & $73^{\circ} 04^{\prime} 56.3^{\prime \prime}$ & $114^{\circ} 55^{\prime} 23.3^{\prime \prime}$ & 3 & $500 \times 500$ \\
\hline 07-SA-14 & $73^{\circ} 07^{\prime} 32.2^{\prime \prime}$ & $114^{\circ} 52^{\prime} 05.1^{\prime \prime}$ & 1 & $300 \times 300$ \\
\hline 07-SA-15 & $73^{\circ} 07^{\prime} 47.3^{\prime \prime}$ & $114^{\circ} 51^{\prime} 54.9^{\prime \prime}$ & 4 & $800 \times 800$ \\
\hline 07-SA-16 & $73^{\circ} 07^{\prime} 45.8^{\prime \prime}$ & $114^{\circ} 51^{\prime} 38.7^{\prime \prime}$ & 4 & $800 \times 800$ \\
\hline 07-SA-17 & $73^{\circ} 11^{\prime} 36.1^{\prime \prime}$ & $114^{\circ} 57^{\prime} 48.1^{\prime \prime}$ & 10 & $500 \times 500$ \\
\hline 07-SA-18 & $73^{\circ} 12^{\prime} 56.2^{\prime \prime}$ & $113^{\circ} 37^{\prime} 14.3^{\prime \prime}$ & 8 & $500 \times 300$ \\
\hline 07-SA-19 & $73^{\circ} 13^{\prime} 17.2^{\prime \prime}$ & $113^{\circ} 37^{\prime} 10.4^{\prime \prime}$ & 1 & $600 \times 500$ \\
\hline 07-SA-20 & $73^{\circ} 22^{\prime} 53.9^{\prime \prime}$ & $113^{\circ} 55^{\prime} 49.9^{\prime \prime}$ & 4 & $700 \times 300$ \\
\hline 07-SA-21 & $73^{\circ} 23^{\prime} 13.5^{\prime \prime}$ & $113^{\circ} 56^{\prime} 56.3^{\prime \prime}$ & 4 & $200 \times 80$ \\
\hline 07-SA-22 & $72^{\circ} 49^{\prime} 32.2^{\prime \prime}$ & $113^{\circ} 17^{\prime} 36.6^{\prime \prime}$ & 8 & $300 \times 200$ \\
\hline 07-SA-23 & $72^{\circ} 46^{\prime} 29.7^{\prime \prime}$ & $112^{\circ} 58^{\prime} 39.5^{\prime \prime}$ & 4 & $600 \times 400$ \\
\hline 07-SA-24 & $72^{\circ} 46^{\prime} 35.5^{\prime \prime}$ & $112^{\circ} 58^{\prime} 13.9^{\prime \prime}$ & 1 & $200 \times 200$ \\
\hline 07-SA-25 & $72^{\circ} 46^{\prime} 39.7^{\prime \prime}$ & $112^{\circ} 58^{\prime} 13.0^{\prime \prime}$ & 1 & $150 \times 150$ \\
\hline 07-SA-26 & $72^{\circ} 19^{\prime} 12.0^{\prime \prime}$ & $111^{\circ} 11^{\prime} 20.4^{\prime \prime}$ & 86 & $400 \times 400$ \\
\hline 07-SA-27 & $72^{\circ} 19^{\prime} 14.5^{\prime \prime}$ & $111^{\circ} 11^{\prime} 13.8^{\prime \prime}$ & 71 & $500 \times 400$ \\
\hline 07-SA-28 & $72^{\circ} 04^{\prime} 16.9^{\prime \prime}$ & $111^{\circ} 06^{\prime} 29.3^{\prime \prime}$ & 41 & $500 \times 300$ \\
\hline 07-SA-29 & $72^{\circ} 04^{\prime} 5.7^{\prime \prime}$ & $111^{\circ} 06^{\prime} 25.3^{\prime \prime}$ & 37 & $180 \times 120$ \\
\hline 07-SA-30 & $72^{\circ} 04^{\prime} 7.0^{\prime \prime}$ & $111^{\circ} 06^{\prime} 40.0^{\prime \prime}$ & 36 & $200 \times 180$ \\
\hline 07-SA-31 & $72^{\circ} 04^{\prime} 15.2^{\prime \prime}$ & $111^{\circ} 07^{\prime} 3.4^{\prime \prime}$ & 38 & $150 \times 150$ \\
\hline 07-SA-32 & $71^{\circ} 44^{\prime} 51.7^{\prime \prime}$ & $111^{\circ} 07^{\prime} 46.2^{\prime \prime}$ & 50 & $100 \times 100$ \\
\hline 07-SA-33 & $71^{\circ} 44^{\prime} 50.9^{\prime \prime}$ & $111^{\circ} 07^{\prime} 55.2^{\prime \prime}$ & 50 & $600 \times 400$ \\
\hline 07-SA-34 & $71^{\circ} 30^{\prime} 10.8^{\prime \prime}$ & $110^{\circ} 49^{\prime} 08.4^{\prime \prime}$ & 80 & $400 \times 150$ \\
\hline 07-SA-35 & $72^{\circ} 03^{\prime} 57.5^{\prime \prime}$ & $113^{\circ} 54^{\prime} 49.3^{\prime \prime}$ & 15 & $300 \times 100$ \\
\hline
\end{tabular}

\footnotetext{
${ }^{a}$ Approximated by a circle or ellipse with these diameters
}

\section{Materials and methods}

Field work

Samples were collected during a joint RussianGerman expedition in the summer of 2007. The study sites included 35 lakes distributed along a north-south transect across the Anabar region $\left(71^{\circ} 30^{\prime} 10.8^{\prime \prime}-\right.$ $73^{\circ} 23^{\prime} 13.5^{\prime \prime} \mathrm{N}$ ) (Fig. 1; Table 1). To avoid disturbances in the sediment deposition, we sampled only lakes that were over $0.9 \mathrm{~m}$ deep, not fed by large rivers, and were without anthropogenic impact. Most of the lakes were $>2.5 \mathrm{~m}$ deep, but some shallow ponds in the Arctic tundra were included in the 
Table 2 Statistical summary for the limnological measurements of the study lakes in the Anabar region of Yakutia

\begin{tabular}{|c|c|c|c|c|c|c|}
\hline Variable & Min & Max & Mean & Median & SD & Skew \\
\hline $\mathrm{T}_{\text {air July }}\left({ }^{\circ} \mathrm{C}\right)$ & 10.2 & 12.1 & 11.2 & 11.0 & 0.51 & 0.09 \\
\hline Water depth (m) & 0.90 & 8.00 & 3.90 & 3.35 & 2.39 & 0.27 \\
\hline Secchi depth (m) & 0.50 & 4.50 & 1.59 & 1.50 & 0.85 & 1.44 \\
\hline Conductivity $\left(\mu \mathrm{S} \mathrm{cm}^{-1}\right)$ & 16.00 & 277.00 & 51.10 & 33.00 & 49.20 & 3.25 \\
\hline $\mathrm{HCO}_{3}^{-}\left(\mathrm{mg} \mathrm{L}^{-1}\right)$ & 4.10 & 36.10 & 15.84 & 13.70 & 9.23 & 0.77 \\
\hline $\mathrm{pH}$ & 4.85 & 7.55 & 7.00 & 7.18 & 0.58 & -2.57 \\
\hline $\mathrm{Cl}^{-}\left(\mathrm{mg} \mathrm{L}^{-1}\right)$ & 0.27 & 63.00 & 5.25 & 1.12 & 11.74 & 3.95 \\
\hline $\mathrm{SO}_{4}{ }^{2-}\left(\mathrm{mg} \mathrm{L}^{-1}\right)$ & 0.11 & 9.94 & 0.73 & 0.22 & 1.84 & 4.63 \\
\hline $\mathrm{Al}^{3+}\left(\mu \mathrm{g} \mathrm{L}^{-1}\right)$ & 21.10 & 200.00 & 59.55 & 30.30 & 57.79 & 1.73 \\
\hline $\mathrm{Ca}^{2+}\left(\mathrm{mg} \mathrm{L}^{-1}\right)$ & 0.94 & 9.49 & 3.78 & 3.42 & 2.21 & 0.96 \\
\hline $\mathrm{Fe}_{\text {total }}\left(\mu \mathrm{g} \mathrm{L}^{-1}\right)$ & 24.70 & 587.00 & 243.46 & 198.50 & 146.77 & 0.68 \\
\hline $\mathrm{Mg}^{2+}\left(\mathrm{mg} \mathrm{L}^{-1}\right)$ & 0.67 & 4.96 & 1.77 & 1.73 & 1.00 & 1.04 \\
\hline $\mathrm{Na}^{+}\left(\mathrm{mg} \mathrm{L}^{-1}\right)$ & 0.21 & 36.40 & 3.45 & 0.99 & 7.08 & 3.86 \\
\hline $\mathrm{Si}^{4+}\left(\mathrm{mg} \mathrm{L}^{-1}\right)$ & 0.27 & 63.00 & 5.25 & 1.12 & 11.74 & 3.95 \\
\hline $\mathrm{NO}_{3}^{-}\left(\mathrm{mg} \mathrm{L}^{-1}\right)$ & $<0.15$ & & & & & \\
\hline $\mathrm{Mn}^{2+}\left(\mu \mathrm{g} \mathrm{L}^{-1}\right)$ & $<20$ & & & & & \\
\hline $\mathrm{TP}\left(\mathrm{mg} \mathrm{L}^{-1}\right)$ & $<0.1$ & & & & & \\
\hline
\end{tabular}

The abbreviation SD refers to the standard deviation, Skew refers to skewedness (adjusted Fisher-Pearson standardized moment coefficient included in Excel). Concentrations of $\mathrm{NO}_{3}{ }^{-}, \mathrm{Mn}^{2+}$ and $\mathrm{TP}$ were mostly below the detection limits Detection limits are given in the table

investigation, to better represent this zone within the data set. The majority of the lakes were of medium size (area $=0.25-20$ ha). Details are given in the Tables 1 and 2.

Hydrochemical samples and Secchi-disk measurements for each site were taken from the surface water layer $(0.5-1 \mathrm{~m})$ at the lake centre. Alkalinity and acidity were determined using titrimetric test kits (Macherey-Nagel, Visocolor series). We measured $\mathrm{pH}$, water temperature, oxygen concentration and electrical conductivity (EC) using a handheld multiparameter instrument (WTW 340i) equipped with appropriate sensors (pH: SenTix 41; Oxygen: CellOx 325; EC and temperature: Tetracon 325). Water samples for ion analysis were passed through a cellulose-acetate filter (pore size $0.45 \mu \mathrm{m}$ ) in the field. Samples for elemental (cation) analysis were acidified using $\mathrm{HNO}_{3}$. Samples for anion analysis and residue samples were stored cool. Surface sediments were collected from the deepest point of each lake using an Eckman-Birge dredge in modification of Lenz (Blomqvist 1990), which has an option to cut the sampled sediments horizontally in order to separate the upper $1-\mathrm{cm}$ layer with no disturbance. The sediments were stored in cold storage at $4{ }^{\circ} \mathrm{C}$ prior to analysis for invertebrate remains.

Laboratory methods. Analyses of water and subfossil Cladocera

Water samples were analysed at the Alfred Wegener Institute (Potsdam, Germany). The chemical analyses encompassed conductivity, $\mathrm{pH}$, oxygen concentration, dissolved organic carbon (DOC), total phosphorus (TP), chloride $\left(\mathrm{Cl}^{-}\right)$, sulphate $\left(\mathrm{SO}_{4}{ }^{2-}\right)$, nitrite $\left(\mathrm{NO}_{2}{ }^{-}\right)$, nitrate $\left(\mathrm{NO}_{3}{ }^{-}\right)$, carbonate $\left(\mathrm{HCO}_{3}{ }^{-}\right)$, calcium $\left(\mathrm{Ca}^{2+}\right)$, sodium $\left(\mathrm{Na}^{+}\right), \mathrm{Si}^{4+,} \mathrm{Al}^{3+}, \mathrm{Fe}_{\text {total }}, \mathrm{Mg}^{2+}, \mathrm{Mn}^{2+}$.

Only 31 of the initial 35 lakes contained sufficient cladoceran remains for analysis. The sample preparation method used for cladoceran analyses in our study was an adaptation of the subfossil preparation technique described by Korhola and Rautio (2001) and the method of Jeppesen et al. (2001). Between 4 and $8 \mathrm{~g}$ of fresh surface sediment sub-samples were heated in $10 \% \mathrm{KOH}$ at $75{ }^{\circ} \mathrm{C}$ for approximately $30 \mathrm{~min}$. The sediments were then rinsed through 125 and $63 \mu \mathrm{m}$ sieves in order to facilitate identification of remains. The material retained on sieves was transferred to 
small vials containing distilled water and a few drops of ethanol to prevent fungal growth. Two to three drops of a safranin solution was added to stain any cladocerans remains. Sub-samples were analysed using a light microscope at 40-400× magnification. The chitinous remains of cladoceran (post-abdomens, claws, mandibles, sections of antennae, ephippia and remains of carapaces) were identified with reference to Flössner (2000), Frey (1959, 1973), Smirnov (1974), Szeroczyńska and Sarmaja-Korjonen (2007).

At least 100 individuals per sample were counted from each sub-sample, both fractions were counted wholly, and if there were not enough remains, another subsample was prepared. All individuals were identified to the lowest taxonomic level possible. We had difficulty separating species of Daphnia based solely on postabdominal claws morphology. Most daphnid remains were divided into two broad groups as has been done in other investigations (Davidson et al. 2007; Sweetman et al. 2010). Remains containing teeth of middle pecten of the postabdominal claws that were significantly larger than teeth of proximal or distal pecten were classified as Daphnia pulex complex, whereas remains with teeth of middle pecten of similar size to the proximal and distal pectens were classified as D. longispina complex.

\section{Data analyses}

The environmental data included several physical, chemical and biological variables considered to be potentially important in structuring cladoceran communities. These included mean July air temperature, latitude, longitude, altitude, vegetation, water depth, Secchi depth, conductivity, $\mathrm{pH}$, oxygen concentration, $\mathrm{DOC}, \mathrm{Cl}^{-}, \mathrm{SO}_{4}^{2-}, \mathrm{NO}_{2}{ }^{-}, \mathrm{HCO}^{-}, \mathrm{Al}^{3+}, \mathrm{Si}^{4+}, \mathrm{Ca}^{2+}$, $\mathrm{Mg}^{2+}$, and $\mathrm{Na}^{+}$concentrations. TP, $\mathrm{Mn}^{2+}$ and $\mathrm{NO}_{3}{ }^{-}$ were eliminated from the analysis because their concentrations were mostly below the detection limits $\left(\mathrm{TP}<0.1 \mathrm{mg} \mathrm{l}^{-1}, \mathrm{Mn}^{2+}<20 \mu \mathrm{g} \mathrm{l}^{-1}, \mathrm{NO}_{3}{ }^{-}<\right.$ $0,15 \mathrm{mg} \mathrm{l}^{-1}$, Table 2). The mean July temperature $\left(\mathrm{T}_{\text {July }}\right)$ for the sampled lakes was calculated from a gridded climate data set (New et al. 2002) measured $2 \mathrm{~m}$ above the ground using standard meteorological screens. Using these data, we estimated the mean air temperature at each lake via the spatial interpolation of elevation and distance from the coast. According to the calculation, the lakes are situated within a range with mean July air temperatures from +10.2 to $+12.1{ }^{\circ} \mathrm{C}$ (Table 2).

Normality of distribution of environmental parameters was tested using Fisher-Pearson standardized moment coefficient included in Excel. Values that exceeded two standard errors of skewness (regardless of sign) were identified as significantly skewed (Sokal and Rohlf 1995). Any environmental variables with a skewed distribution (altitude, conductivity, Secchi depth, $\left.\mathrm{Cl}^{-}, \mathrm{SO}_{4}{ }^{2-}, \mathrm{NO}_{2}{ }^{-}, \mathrm{Al}^{3+}, \mathrm{Fe}_{\text {total }}\right)$ were $\mathrm{ln}$ $(\mathrm{x}+1)$ transformed, where $\mathrm{x}$ was the environmental variable under consideration. To reduce the variances across the cladoceran taxa, the percent abundances were square-root transformed prior to all numerical analyses.

A detrended correspondence analysis (DCA) was applied to the cladoceran data to calculate the sampled environmental gradient length. This was necessary to choose between unimodal or linear numerical techniques when estimating the relationship between the cladoceran assemblages and environmental variables (Birks 1995).

Variance inflation factors (VIF) were used to identify the intercorrelated variables. Variables with high VIFs $(>20)$ were eliminated one at a time beginning with the highest until all of the VIFs were below 20 (ter Braak and Prentice 1988). The significance of the environmental variables was tested using a Monte Carlo test with 999 random permutations ( $p \leq 0.05$ ) (Hall and Smol 1996). To determine the relationships between the environmental variables and cladoceran taxa distribution and select those that best explained the cladoceran assemblage variation, a set of redundancy analysis (RDAs) separately constrained to each environmental variable was run and the ratios between the constrained axis $(\lambda 1)$ and the unconstrained axis $(\lambda 2)$ were calculated. Higher $\lambda 1 \backslash \lambda 2$ show more relative strength of each environmental variable (Hall and Smol 1996; DeSellas et al. 2008).

Ordinations and estimation of VIFs were performed using CANOCO software, version 4.5 (ter Braak and Šmilauer 2002). TILIA version 2.0.b.4 was used to generate a cladoceran percentage diagram (Grimm 1993). The program CONISS was used to perform a stratigraphically constrained incremental sum-ofsquares cluster analysis and identify the major groups in lake composition throughout the transect (Grimm 1987). 
Table 3 Characteristics of the cladoceran assemblages in lakes of groups I-III, separated by constrained cluster analysis (CONISS)

\begin{tabular}{llrl}
\hline Variable & I & \multicolumn{1}{l}{ II } & III \\
\hline N taxa per lake & 7.78 & 11.69 & 9.15 \\
H (Shannon Index) & 1.58 & 1.99 & 1.72 \\
I (evenness) & 0.78 & 0.82 & 0.78 \\
\hline
\end{tabular}

Species diversity and evenness were calculated for each sample using the Shannon Index of Diversity (H) (Shannon and Weaver 1963) and Pielou Index (I) (Pielou 1966), respectively.

\section{Results}

General composition of subfossil cladocerans from the Anabar region

The investigated lakes were slightly acidic to neutral and generally dilute. Analysis of the ion composition showed that $\mathrm{Ca}^{2+}$ and $\mathrm{Mg}^{2+}$ dominated the cations with $\mathrm{HCO}_{3}{ }^{-}$the primary anion. The original hydrochemical data will be presented and discussed elsewhere.

The cladoceran assemblages were quite rich and diverse in all lakes with relatively stable structures, as reflected by the high evenness indices (Table 3 ). A total of 28 cladoceran taxa belonging mostly to the family Chydoridae were identified in these lakes. None of the taxa occurred in all lakes. The most common cladocerans taxa were Chydorus sphaericus (O.F. Müller, 1785), Eurycercus spp., Alona rectangula Sars, 1861, Acroperus harpae (Baird 1834) and D. pulex agg. (frequency of occurrence $>50 \%$ ). The species richness (the total number of taxa per lake) ranged between 5 (lakes 05, 14, 18) and 20 (lake 24) with a median of nine which was not significantly correlated to any of the environmental variables measured. The most abundant cladoceran taxon in the modern samples was $C$. sphaericus, which had a mean relative abundance of $44.6 \%(\sigma= \pm 4.5 \%)$ across all lakes and reached an abundance of over $50 \%$ in 13 of the 31 lakes (Fig. 2).

Constrained cluster analysis (CONISS), based on the structure of the cladoceran community, revealed three groups of lakes in the investigated area (Fig. 2).
The clusters show a clear geographic pattern reflecting vegetation zonation into typical tundra, southern tundra and forest-tundra (Fig. 1). However, the cladoceran assemblage from lake 27 was clustered with the forest-tundra lakes, although this lake is situated in the tundra zone $(30 \mathrm{~km}$ north of the tree line observed from the helicopter in field) (Fig. 2).

The first cluster revealed by CONISS was formed by 9 northern lakes located in the typical tundra zone (mean $\mathrm{T}_{\text {July }}=10.6{ }^{\circ} \mathrm{C}$, range between 10.2 and $10.9^{\circ} \mathrm{C}$ ). Several littoral taxa, including C. sphaericus, Alona rustica var. tuberculata, Eurycercus spp. and $D$. pulex agg. were the most abundant in this environment (Fig. 2). The species richness (N) and Shannon Diversity Index $(\mathrm{H})$ in this group of lakes was lower than for southern tundra lakes, however the evenness, which reflects the structural stability of the cladoceran communities, was at the same level, or higher than in in southern lakes (Table 3).

Lakes from the southern tundra (cluster II; mean $\mathrm{T}_{\text {July }}=11.2^{\circ} \mathrm{C}$, range $11.0-11.7^{\circ} \mathrm{C}$ ) were dominated by diverse littoral and pelagic cladoceran assemblages (C. sphaericus, Bosmina longirostris (O. F. Müller, 1785), Eubosmina longispina Leydig, 1860, Bosmina sp., A. rectangula Sars, 1862). The Shannon Index and evenness for this group of lakes were higher than for group I and II (Table 3).

All of the lakes in cluster III, except lake 27 were located in the forest-tundra zone (mean $\mathrm{T}_{\text {July }}=11.8{ }^{\circ} \mathrm{C}$, range $11.7-12.1{ }^{\circ} \mathrm{C}$ ). The most common taxa were $C$. sphaericus, A. rectangula and Daphnia longispina agg. Interestingly, a dominant taxon in the northern part of the transect from the family Daphnidae, D. pulex agg., was replaced in the forest-tundra zone lakes by $D$. longispina agg. (Fig. 3). Cladoceran assemblages in this cluster were more diverse and had a higher evenness than in lakes in the typical tundra zone (Table 3).

Multivariate analysis

The DCA revealed a gradient length of 2.971 SD units, which is an intermediate gradient length and suggests either linear or unimodal ordination methods might be appropriate (ter Braak and Šmilauer 2002). RDA axis $1(\lambda=0.174)$ and axis $2(\lambda=0.157)$ were both significant $(p \leq 0.05)$ and explained $33.1 \%$ of variance of species data (Table 4). Constrained RDA on individual environmental variables with Monte Carlo 


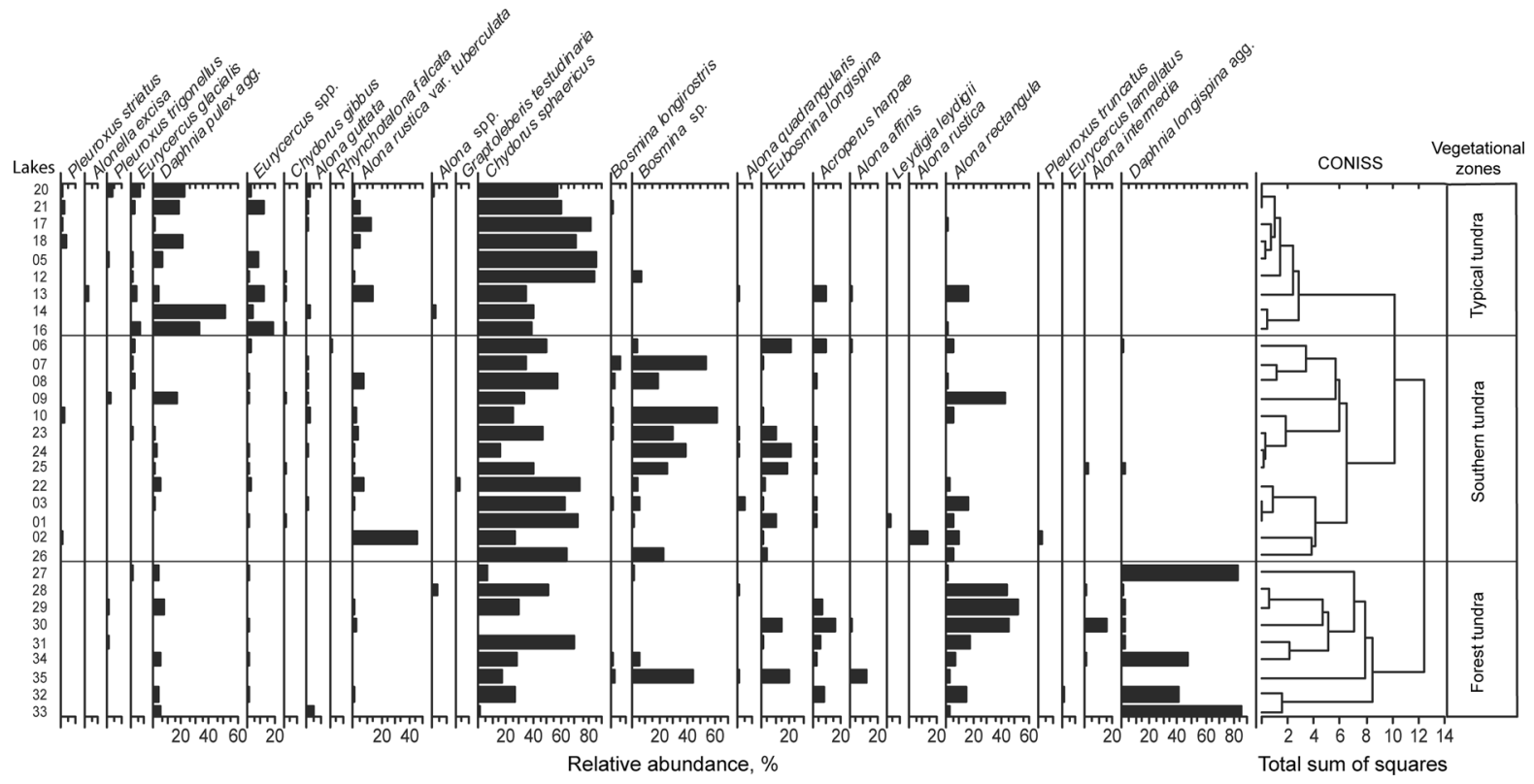

Fig. 2 Distribution of the most common cladoceran taxa found in the studied lakes based on the occurrence of their remains in the lake sediments. Lakes are ordered by $\mathrm{T}_{\text {July }}$ with vegetational/ecoclimatic zones indicated to the right of the diagram

permutation tests (999 permutations) identified environmental variables that significantly $(p \leq 0.05)$ explained the taxonomic data variation: $\mathrm{T}_{\mathrm{July}}$, water depth, $\mathrm{SO}_{4}{ }^{2-}$ and $\mathrm{Si}^{4+}$ (Fig. 3). $\mathrm{T}_{\text {July }}$ and $\mathrm{Si}^{4+}$ correlated to RDA axis 1, while water depth and $\mathrm{SO}_{4}{ }^{2-}$ correlated to RDA axis 2 .

Of the four identified significant environmental variables, $\mathrm{T}_{\text {July }}$ featured the highest percentage $(17.4 \%)$ of explained variance and had the highest $\lambda_{1} / \lambda_{2}$ ratio (0.66) if tested in an RDA with only a single constraining environmental variable (Table 4). The latter measure in particular indicates how effectively the variance in the species data was captured by a particular gradient (Korhola et al. 2000). The results suggest that the relationship between the cladoceran distribution in this data-set and $\mathrm{T}_{\text {July }}$ is sufficiently strong to be promising for the future development of a regional transfer function to reconstruct past mean July temperatures from cladoceran data in palaeoenvironmental investigations. The sites with high axis 1 scores were clustered in the top right portion of the biplot. These lakes are located in the typical tundra zone in the North at low elevation and were shallower than the more southern lakes (water depth: mean $3.17 \mathrm{~m}$, range $1.0-7.4 \mathrm{~m}$ ). Lakes with low axis 2 scores are relatively deep (mean $>6.5 \mathrm{~m}$, range
$0.9->10.0 \mathrm{~m})$ and most are located in the southern tundra and characterised by diverse littoral and pelagic cladoceran assemblages (C. sphaericus, B. longirostris, E. longispina, Bosmina sp. and A. rectangula) (Fig. 3a,3b). Lakes with high axis 2 and low axis 1 scores also came from the southern part of the transect, though mostly from the forest-tundra zones with higher elevations and had high $\mathrm{Si}^{4+}$ ion concentrations (Fig. 3b).

There was a separation of littoral and pelagic cladocerans along the second RDA axis that was related with lake depth. Littoral cladocerans generally occurred in shallow lakes (Fig. 3a: different taxa of the genera Pleuroxus, Eurycercus and Alona), whereas some pelagic cladocerans occurred in higher relative abundances in relatively deep, clear lakes (Fig. 3a: e.g., Bosmina sp. and B. longirostris). A typical profundal cladoceran species found in the deep lakes was Leydigia leydigii (Leydig 1860). Only one pelagic taxon, the D. pulex complex, was abundant in the shallow coloured lakes (Fig. 3a).

Overall, the ordination results supported the classification of the lakes made on the basis of CONISS (Fig. 2). Cladoceran assemblages have the strongest relationship to the climate related parameters $\left(\mathrm{T}_{\mathrm{July}}\right.$, vegetation type) and lake water depth. 

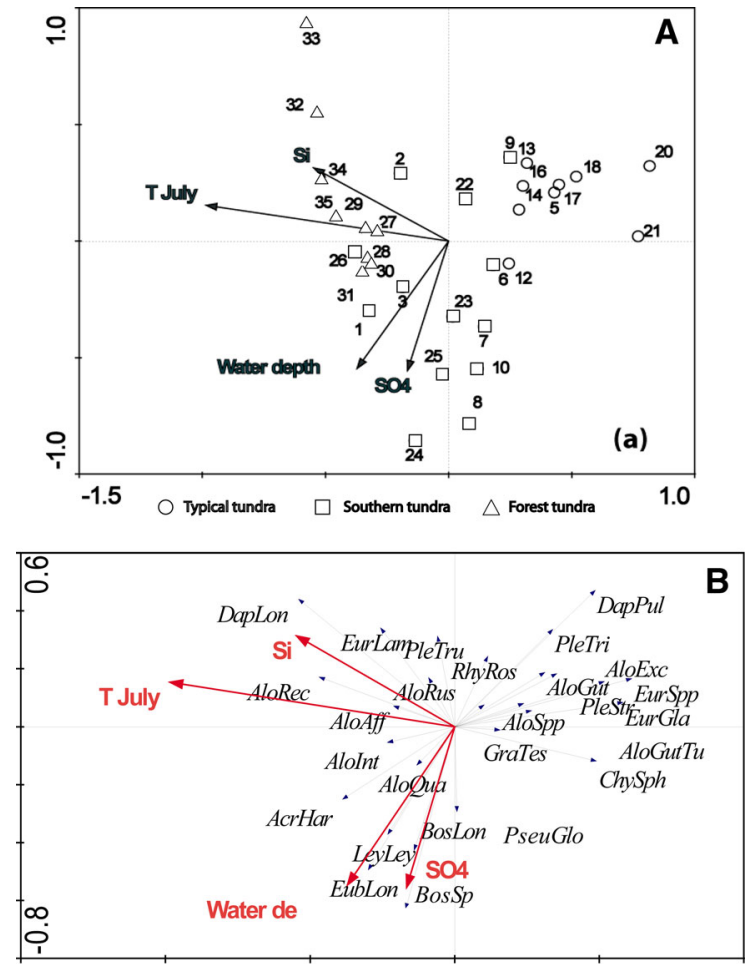

$-1.5$

1.0

Fig. 3 Redundancy analysis ordination plot illustrating the relationship between the most significant ecological factors and both $\mathbf{a}$ the sites and $\mathbf{b}$ the most frequent cladoceran taxa. The taxon codes are given in Table 1

\section{Discussion}

Abundance and habitat characteristics of cladoceran taxa

It is unfortunately impossible to make an intraregional comparison of subfossil Cladocera communities because of the total absence of such data for the
Siberian North. A comparison of our data to the data sets from other regions indicate the species richness and total number of taxa in our investigation was similar to that of Cladocera in thermokarst lakes from permafrost zones along the tree line in Alaska, where 27 Cladocera taxa were identified from the study lakes (Sweetman and Smol 2006), in Canada, where twentynine cladoceran taxa were identified (Sweetman et al. 2010) and Fennoscandia, where a total of 29 cladoceran taxa representing 19 genera were identified (Korhola 1999).

The most abundant taxa in our investigation can be classified as subarctic taxa according to their latitudinal affinities, such as E. longispina, Alona affinis (Leydig 1860), A. harpae and Eurycercus lamellatus (O. F. M., 1776) (Rautio 1998; Korhola 1999) (Table 5). Many of these taxa are cold-tolerant, tolerant of nutrient deficits and adapted to the oligotrophic conditions characteristic of the majority of the investigated lakes (concentration of TP in all of the investigated lakes was below $0.10 \mu \mathrm{g}^{-1}$ ).

Subfossil cladoceran assemblages in Anabar basin included planktonic and benthic taxa. The true planktonic taxa in the studied lakes were $D$. pulex agg., $D$. longispina agg. and taxa from the family Bosminidae. The most characteristic benthic profundal taxon was $L$. leydigii.

Most of the cladocerans in our investigation belonged to littoral species, which occur among macrophytes and in muddy substrate within the macrophyte zone at the lake margins. The littoral component was represented by $C$. sphaericus, $A$. rectangula and other taxa from the family Chydoridae. The dominant taxon, C. sphaericus, is probably a complex of species that comprise several ecologically and geographically distinct species (Belyaeva and

Table 4 The results of DCA and RDA of the cladoceran data from North Siberia

\begin{tabular}{|c|c|c|c|c|c|c|c|c|}
\hline & $\begin{array}{l}\text { DCA } \\
\text { Axis } 1\end{array}$ & Axis 2 & $\begin{array}{l}\text { RDA } \\
\text { Axis } 1\end{array}$ & Axis 2 & $\begin{array}{l}\text { RDA } \\
\mathrm{T}_{\text {July }} \\
\lambda 1 / \lambda 2\end{array}$ & $\begin{array}{l}\text { RDA } \\
\text { WD } \\
\lambda 1 / \lambda 2\end{array}$ & $\begin{array}{l}\mathrm{RDA} \\
\mathrm{Si}^{4+} \\
\lambda 1 / \lambda 2\end{array}$ & $\begin{array}{l}\mathrm{RDA} \\
\mathrm{SO}_{4}^{2-} \\
\lambda 1 / \lambda 2\end{array}$ \\
\hline Eigenvalue & 0.672 & 0.333 & 0.174 & 0.157 & $0.172 / 0.258$ & $0.085 / 0.267$ & $0.082 / 0.250$ & $0.074 / 0.263$ \\
\hline Gradient length (SD) & 2.971 & 2.914 & - & - & - & - & & - \\
\hline $\begin{array}{l}\% \text { of variance explained } \\
p \text { value }\end{array}$ & 26.5 & 13.1 & 17.4 & 15.7 & $\begin{array}{l}17.4 \\
0.001\end{array}$ & $\begin{array}{l}8.5 \\
0.010\end{array}$ & $\begin{array}{l}8.2 \\
0.018\end{array}$ & $\begin{array}{l}7.4 \\
0.028\end{array}$ \\
\hline
\end{tabular}

$p$ values were assessed by 999 unrestricted Monte Carlo permutation tests

$W D$ water depth 
Table 5 List of non-rare cladoceran taxa (relative abundance of at least $2 \%$ in at least one study lake) from the studied lakes and their zoogeographic characteristics in north Yakutian lakes

\begin{tabular}{|c|c|c|c|}
\hline Taxon & Note & $\#$ Occ & $\begin{array}{l}\text { Geographical } \\
\text { range }^{\mathrm{a}}\end{array}$ \\
\hline Acroperus harpae & AcrHar & 19 & $\mathrm{H}$ \\
\hline Alona affinis & AloAff & 12 & $\mathrm{~K}$ \\
\hline Alona guttata & AloGut & 11 & $\mathrm{~K}$ \\
\hline Alona intermedia & AloInt & 4 & $\mathrm{~K}$ \\
\hline Alona quadrangularis & AloQua & 6 & $\mathrm{H}$ \\
\hline Alona rectangula & AloRec & 24 & $\mathrm{~K}$ \\
\hline Alona rustica & AloRus & 2 & $\mathrm{H}$ \\
\hline $\begin{array}{l}\text { Alona rustica var. } \\
\text { tuberculata }\end{array}$ & AloRusTub & 17 & $\mathrm{P}$ \\
\hline Alona spp. & AloSpp & 9 & \\
\hline Alonella excisa & AloExc & 3 & $\mathrm{~K}$ \\
\hline Bosmina longirostris & BosLon & 8 & $\mathrm{~K}$ \\
\hline Bosmina sp. & BosSp & 17 & \\
\hline Chydorus sphaericus & ChySph & 33 & $\mathrm{~K}$ \\
\hline $\begin{array}{l}\text { Daphnia longispina } \\
\text { agg. }\end{array}$ & DapLon & 10 & \\
\hline Daphnia pulex agg. & DapPul & 19 & \\
\hline Eubosmina longispina & EubLon & 15 & $\mathrm{P}$ \\
\hline Eurycercus glacialis & EurGla & 13 & A \\
\hline Eurycercus lamellatus & EurLam & 5 & $\mathrm{~K}$ \\
\hline Eurycercus spp. & EurSpp & 25 & \\
\hline $\begin{array}{r}\text { Graptoleberis } \\
\text { testudinaria }\end{array}$ & GraTes & 3 & $\mathrm{~K}$ \\
\hline Leydigia leydigi & LeyLey & 6 & $\mathrm{H}$ \\
\hline Pleuroxus striatus & PleStr & 7 & $\mathrm{H}$ \\
\hline Pleuroxus trigonellus & PleTri & 5 & $\mathrm{P}$ \\
\hline Pleuroxus truncatus & PleTru & 1 & $\mathrm{H}$ \\
\hline $\begin{array}{l}\text { Pseudochydorus } \\
\text { globosus }\end{array}$ & PseuGlo & 8 & $\mathrm{H}$ \\
\hline Rhynchotalona falcata & Rhyfal & 1 & $\mathrm{H}$ \\
\hline
\end{tabular}

Occ number of occurrences, $A$ arctic, $K$ cosmopolite, $H$ holarctic, $P$ palearctic

a Information about zoogeography was taken from Flößner (2000), Manuilova (1964), Smirnov (1974, 1996)

Taylor 2009). Chydorus sphaericus is a nearshore and littoral ubiquitous taxon that may be abundant in eutrophic conditions as well as oligotrophic conditions, but an increase in this taxon is typical sign of increased levels of nutrients and of eutrophication processes (Flössner 2000; Nevalainen and Luoto 2013; Table 5).

Taxa in this data set that are typical for deep lakes were mostly planktonic, such as $B$. longirostris, $E$. longispina and Bosmina sp. Typical benthic profundal species included $L$. leydigii, whereas A. harpae was the only littoral taxon with preference for deeper sites. Alonella excisa (Fischer 1854), A. affinis, Pleuroxus trigonellus (O. F. Müller, 1776) and other littoral species were distinctly associated with shallow lakes. These results are in agreement with other studies on the present-day cladoceran distribution for lakes in Finnish Lapland (Rautio 1998; Korhola et al. 2000).

Some Cladocera taxa have wide ecological tolerance and are able to colonise various types of aquatic environment, whereas other taxa are more restricted to particular conditions and narrower ecological niches (Flössner 2000). Therefore, despite most of the taxa appearing to be widely distributed and present in lakes from all three ecozones, some cladoceran groups are more specifically affiliated to a certain ecozone.

The most abundant Cladocera taxa in the typical tundra zone were $C$. sphaericus, Eurycercus glacialis, D. pulex agg. and Alona guttata var. tuberculata. E. glacialis, one of the largest species of cladocerans, inhabits ponds and pools in both Arctic and subarctic regions and has been observed at lower latitudes in Europe and North America (Frey 1973). Eurycercus glacialis is one of few Arctic cladoceran species with a circumpolar distribution and is almost completely limited to tundra zones (Smirnov 1996). Minakawa et al. (2006) reported that on Sakhalin E. glacialis was primarily found in shallow waters (10-30 cm deep) with sandy substrates. Closely related species, E. lamellatus demonstrates a marked preference for the cold, deep, clear and organic-poor waters in the far North (Korhola 1999). This taxon is cold-tolerant Arctic-subarctic according to the classification of Harmsworth (1968). According to Flössner (2000), E. glacialis and the more widely distributed $E$. lamellatus occupy different water bodies: lamellatus inhabits small ponds and glacialis inhabits lakes. However, populations of both species were found in lakes during our investigations and those of Duigan and Frey (1987).

Another relatively abundant taxa in the tundra zone was Alona guttata var. tuberculata. Daphnidae were represented by $D$. pulex complex, which most likely included Daphnia middendorfiana. According to Reed (1959), this species dominated in 170 water bodies in the Arctic North American tundra. Flössner (2000) stated that the distribution of this species was restricted to tundra regions. Similar to our findings, 
DeSellas et al. (2008) reported that D. pulex agg. preferred shallow, coloured lakes in south-central Ontario (Canada).

The lakes in the southern tundra zone were deeper than those from the typical tundra zone. Therefore, more planktonic taxa, such as E. longispina and Bosmina sp. were found there. E. longispina, a taxon typically associated with oligotrophic conditions (Flössner 2000) rather than harsh climatic conditions (Hofmann 1978), was frequently identified.

One of the most significant changes in the structure of cladoceran communities along the investigated transect was the replacement of closely related species along the latitudinal gradient. In the forest tundra $E$. glacialis was replaced by the subarctic species $E$. lamellatus. The dominant species in the tundra and south tundra zones, D. pulex complex, was replaced in forest tundra by Daphnia longispina agg.

Relationships between subfossil cladoceran assemblages and environmental factors

Temperature has been identified as an important factor in the structuring of cladoceran assemblages in Finnish Lapland (Korhola 1999; Sarmaja-Korjonen et al. 2006), Norway (Hessen et al. 2006) and the Yukon and Northwest Territories, Canada (Swadling et al. 2000; Sweetman et al. 2010). This is in agreement with our data. We found that $\mathrm{T}_{\text {July }}$ was significantly correlated with the distribution of subfossil Cladocera in the lakes of the northwestern Yakutia, and $17.4 \%$ of the variance in the taxa data was explained by this variable. This finding implies that cladocerans can not only provide important insight into the impact of changing temperature conditions in northern aquatic ecosystems, but are also likely to be susceptible to future warming.

A second environmental factor that was identified as important for the cladoceran distribution in our lakes was water depth. Several previous studies have recognised the importance of lake depth in influencing cladoceran communities (Korhola 1999; Korhola et al. 2000; Sarmaja-Korjonen and Alhonen 1999). In addition, subfossil cladoceran remains have been previously used by palaeolimnologists to reconstruct changes in the lake depth (Sarmaja-Korjonen and Alhonen 1999). Shallower lakes are typically smaller and more homogeneous but have a larger proportion of littoral habitats relative to deeper lakes (Keller and
Conlon 1994). Accordingly, the abundance of littoral taxa in shallow lakes is higher, while a relatively high pelagic cladoceran abundance was found in deeper lakes.

The correlation between the $\mathrm{Si}^{4+}$ ion concentration and structure of subfossil Cladocera communities found in the lakes of the Anabar region can be indirectly explained by the trophic relationships between cladocerans and diatoms. Diatoms are often the dominant group of phytoplankton in Arctic and subarctic lakes. This also was shown for the region of our investigation, the Anabar river basin (Gabyshev and Gabysheva 2010). It is known that there is a direct link between the seasonal diatom dynamics and changes in the dissolved silica and phosphorus content of the water (Rossolimo 1971). Silica can be a limiting factor for the development of diatom algae that use $\mathrm{Si}$ to produce siliceous frustules. The quantity of diatom algae influences the grazing conditions for some Cladocera species that use them as their primary diet component. For example, the diet of Eurycercus spp. consists primarily of diatoms (Gomphonema spp. Ehrenberg (1832), Tabellaria spp. Grunow (1868)) according to Frey (1973). A similar interrelation between the $\mathrm{Si}$ concentration and Cladocera community structures was found in the small, high-mountain lakes of Switzerland, which have similar ecological conditions to Arctic and subarctic lakes (Lotter et al. 1997). In our investigation, lake conditions were favourable for the development of, and in certain cases, the dominance of diatom production despite the low content of $\mathrm{Si}$ in the water $\left(0.09-1.29 \mathrm{mg} \mathrm{L}^{-1}\right.$, Table 1) (Gabyshev and Gabysheva 2010). Thus, with the shortage of biogenic elements in northern water bodies, the indirect influence of $\mathrm{Si}$ concentrations on hydrobiont communities can be expected.

The sulphate $\left(\mathrm{SO}_{4}{ }^{2-}\right)$ concentrations show relationships with distribution of the Cladocera in our study. The same was found in south-central Ontario (Canada) (DeSellas et al. 2008). Our finding could be connected to the negative water balance in the region and requires further investigations.

We found essential changes in the subfossil Cladocera communities across the small temperature gradient, which is two degrees, crossing the tree line in northwestern Yakutia. Assuming temperatures will rise within the range forecasted by the IPCC (2007), the biological communities of the subarctic tundra are likely to move northward and the northern most 
communities of the Arctic tundra are likely to be lost. Thus the Arctic cladoceran communities will undergo significant changes and species with strict circumpolar distribution (E. glacialis) might disappear from this territory entirely.

The investigation of cladoceran assemblages in northwestern Yakutian lakes has demonstrated the potential of this group of hydrobionts as an indicator of the ecological state of both water bodies and of the changes caused by climate change occurring in the ecosystem. The results obtained encourage further work to create a regional cladoceran-based temperature model appropriate for the Arctic regions of Russia as a whole and Yakutia in particular.

Acknowledgments The authors warmly thank all participants of the summer expedition to northwest Yakutia in 2007. The authors also thank the laboratory teams of the Alfred Wegener Institute for Polar and Marine Research (AWI) in Potsdam, especially Antje Eulenburg for general assistance during sample preparation and analysis and Thomas Böhmer for the map preparation. Larisa Frolova is especially thankful to Dr. Thomas Davidson (Aahrus University) for his help and training her in slide preparation and identification of subfossil Cladocera. The group of authors also expresses sincere gratitude to the anonymous reviewers of this article for their valuable remarks and references. This project was supported by AWI, RNF of RF and by the subsidy of the Russian Government to support the Program of Competitive Growth of KFU among World's Leading Academic Centers.

\section{References}

Anderson NJ, Battarbee RW (1994) Aquatic community persistence and variability: a palaeolimnological perspective. In: Giller PS, Hildrew AG, Raffaelli DG (eds) Aquatic ecology: scale, pattern and process. Blackwell, Oxford, pp 233-259

Arctic Climate Impact Assessment (ACIA) (2005) Arctic climate impact assessment. Cambridge University Press, Cambridge

Arktiki Atlas (1985) Atlas of the Arctic. In: Treshnikov AF, Korotkevich ES, Kruchinin YA, Markov VF (eds) Main Administration for Geodesy and Cartography. Ministry Council of the USSR, Moscow (original in Russian)

Atlas selskogo khozyaistva Yakutskoi ASSR (1989) Agricultural Atlas of the Yakut ASSR. In: Matveev IA (ed) Glavnoe Upravlenie Geodezii i Kartografii. Ministertva Geologii Ochrany Nedr SSSR, Moscow (original in Russian)

Belyaeva M, Taylor DJ (2009) Cryptic species within the Chydorus sphaericus species complex (Crustacea: Cladocera) revealed by molecular markers and sexual stage morphology. Mol Phylogenet Evol 50:534-546

Birks HJB (1995) Quantitative palaeoenvironmental reconstructions. In: Maddy DJ, Brew S (eds) Statistical modelling of quaternary science data. Quaternary Research Association, Cambridge, pp 161-254

Blomqvist S (1990) Sampling performance of Ekman grabsin situ observations and design improvements. Hydrobiologia 206:245-254

Chistyakov GE (1964) Waterresources in Yakutia. Nauka, Moscow (in Russian)

Davidson TA, Sayer CD, Perrow MR, Bramm M, Jeppesen E (2007) Are the controls of species composition similar for contemporary and subfossil cladoceran assemblages? A study of 39 shallow lakes of contrasting trophic status. J Paleolimnol 38:117-134

DeSellas AM, Paterson AM, Sweetman JN, Smol JP (2008) Cladocera assemblages from the surface sediments of southcentral Ontario (Canada) lakes and their relationships to measured environmental variables. Hydrobiologia 600:105-119

Duigan CA, Frey DG (1987) Eurycercus glacialis in Ireland (Cladocera, Chydoridae). Int Revue ges Hydrobiol 72(2):235-249

Flössner D (2000) Die Haplopoda und Cladocera (ohne Bosminidae) Mitteleuropas. Backhuys Publishers, Leiden

Frey DG (1959) The taxonomic and phylogenic significance of the head pores of the Chydoridae (Cladocera). Inter Rev ges Hydrobiol 44:27-60

Frey DG (1973) Comparative morphology and biology of three species of Eurycercus (Chydoridae: Cladocera) with a description of Eurycercus macrocanthus sp. nov. Int Revue ges Hydrob 58:221-267

Frolova LA, Nazarova LB, Pestryakova LA, Herzschuh U (2013) Analysis of the effects of climate-dependent factors on the formation of zooplankton communities that inhabit arctic lakes in the Anabar river basin. Contemp Prob Ecol 6:1-11

Gabyshev VA, Gabysheva OI (2010) Water quality of the Anabar River indicated by phytoplankton structure and hydrochemical characteristics. Contemp Prob Ecol 3:395-400

Gavrilova MK (1998) Klimaty kholodnykh regionov zemli (Climates of cold regions in the world). Russian Science Academy (Siberian Branch Publishers), Yakutsk (in Russian)

Grimm EC (1987) CONISS: a Fortran 77 program for stratigraphically constrained cluster analysis by the method of incremental sum of squares. Comput Geosci 113:13-35

Grimm EC (1993) TILIA 2.0.b.4 (Computer software). Illinois State Museum, Research and Collections Center, Springfield

Hall RI, Smol JP (1996) Paleolimnological assessment of longterm water-quality changes in south-central Ontario lakes affected by cottage development and acidification. Can J Fish Aqua Sci 53:1-17

Harmsworth RV (1968) The developmental history of Blelham Tarn (England) as shown by animal microfossils, with special reference to the Cladocera. Ecol Monogr 38:223-241

Hessen DO, Faafeng BA, Smith VA, Bakkestuen V, Walseng B (2006) Extrinsic and intrinsic controls of zooplankton diversity in lakes. Ecology 87:433-443

Hofmann W (1978) Bosmina (Eubosmina) populations of Grosser Plöner See and Schöhsee lakes during late-glacial and postglacial times. Pol Arch Hydrobiol 25:167-176

Intergovernmental Panel on Climate Change (IPCC) (2007) Report of the intergovernmental panel on climate change. In: 
Solomon S, Qin D, Manning M, Chen Z, Marquis M, Averyt KB, Tignor M, Miller HL (eds) Climate change 2007: the physical science basis. Contribution of Working Group I to the Fourth Assessment. Cambridge University Press, Cambridge Jeppesen E, Leavitt P, De Meester L, Jensen JP (2001) Functional ecology and palaeolimnology: using cladoceran remains to reconstruct anthropogenic impact. Trends Ecol Evol 16:191-198

Karavaev MP, Skryabin SZ (1971) Rastitel'nyi mir Yukutii (Vegetation of Yakutia). Yakutian Publishing House, Yakutsk (in Russian)

Keller W, Conlon M (1994) Crustacean zooplankton communities and lake morphometry in Precambrian Shield lakes. Can J Fish Aquat Sci 51:2424-2434

Kienast F, Wetterich S, Kuzmina S, Schirrmeister L, Andreev AA, Tarasov P, Nazarova L, Kossler A, Frolova L, Kunitsky VV (2011) Paleontological records prove boreal woodland under dry inland climate at today's Arctic coast in Beringia during the last interglacial. Quat Sci Rev 30:2134-2159

Kirilov AF, Kholodov VV, IGl Sobakina et al (2007) Biology of the river Anabar. Publishing House of YSC, Yakutsk (original in Russian)

Korhola A (1999) Distribution patterns of Cladocera in subarctic Fennoscandian lakes and their potential in environmental reconstruction. Ecography 22:357-373

Korhola A, Rautio M (2001) Cladocera and other branchiopod crustaceans. In: Smol JP, Birks JB, Last WM (eds) Tracking environmental change using lake sediments, vol: zoological indicators. Kluwer Academic Publishers, Dordrecht, pp 5-41

Korhola A, Olander H, Blom T (2000) Cladoceran and chironomid assemblages as qualitative indicators of water depth in subarctic Fennoscandian lakes. J Paleolimnol 24:43-54

Lotter AF, Birks HJB, Hofmann W, Marchetto A (1997) Modern diatom, Cladocera, chironomid, and chrysophyte cyst assemblages as quantitative indicators for the reconstruction of past environmental conditions in the Alps. I. Climate. J Paleolimnol 18:395-420

Manuilova EF (1964) Vetvistousye rachki fauny SSSR. Nauka, Moskva-Leningrad. (Cladocera of the USSR) (In Russian)

Minakawa N, Tanaka S, Bogatov VV (2006) Occurrence of Eurycercus (Teretifrons) glacialis (Lilijeborgem 1887) (Cladocera, Chydoridae) on Sakhalin Island. Biodivers Biogeogr Kuril Isl Sakhalin 2:111-114

Nevalainen L, Luoto TP (2013) Limnological deterioration forces community and phenotypic changes in Cladocera: tracking eutrophication Mallusjärvi, a lake in southern Finland. Boreal Environ Res 18:209-222

New M, Lister D, Hulme M, Makin I (2002) A high-resolution data set of surface climate over global land areas. Climate Res 21:1-25

Petersen A (2010) Emerging issues and challenges. In: Kurvits T, Alfthan B, Mork E (eds) Arctic biodiversity trends 2010 - selected indicators of change. CAFF International Secretariat, Akureyi, pp 15-16

Pielou EC (1966) The measurement of diversity in different types of biological collections. J Theor Biol 13:131-144

Rautio M (1998) Community structure of crustacean zooplankton in subarctic ponds-effects of altitude and physical heterogeneity. Ecography 21:327-335
Reed EB (1959) The distribution and ecology of freshwater entomostraca in Arctic and subarctic North America. Ph.D. thesis, University of Saskatchewan, SK, Canada

Rossolimo LL (1971) Ozernoe nakoplenie kremniia i ego tipologicheskoe znachenie (Lake accumulation of silica and its topological meaning). Nauka, Leningrad (original in Russia)

Samchyshyna L, Hansson L-A, Christoversen K (2008) Patterns in the distribution of Arctic freshwater zooplankton related to glaciation history. Polar Biol 31:1427-1435

Sarmaja-Korjonen K, Alhonen P (1999) Cladoceran and diatom evidence of lake-level fluctuations from a Finnish lake and the effect of aquatic-moss layers on microfossil assemblages. J Paleolim 22:277-290

Sarmaja-Korjonen K, Nyman M, Kultti S, Valiranta M (2006) Palaeolimnological development of Lake Njargajavri, northern Finnish Lapland, in a changing Holocene climate and environment. J Paleolimnol 35:65-81

Shannon CE, Weaver W (1963) The mathematical theory of communication. Univ. Illinois Press, Illinois

Smirnov NN (1974) Fauna of the U.S.S.R., Crustacea. Academy of Sciences of the U.S.S.R. Translated from Russian, Israel Program for Scientific Translations, Jerusalem, New Series No. 101

Smirnov NN (1996) Cladocera: the Chydorinae and Sayciinae (Chydoridae) of the world. Guides to the identification of the microivertebrates of the Continental Waters of the world. SPB Academic Publishing, Amsterdam

Sokal RR, Rohlf FJ (1995) Biometry: the principles and practice of statistics in biological research. W. H. Freeman and Co, New York

Swadling KM, Pienitz R, Nogrady T (2000) Zooplankton community composition of lakes in the Yukon and Northwest Territories (Canada): relationship to physical and chemical limnology. Hydrobiologia 431:211-224

Sweetman JN, Smol JP (2006) Patterns in the distribution of Cladocerans (Crustacea: Branchiopoda) in lakes across a north-south transect in Alaska, USA. Hydrobiologia 553:277-291

Sweetman JN, Rühland KM, Smol JP (2010) Environmental and spatial factors influencing the distribution of cladocerans in lakes across the central Canadian Arctic treeline region. J Limnol 69:1-12

Szeroczyńska K, Sarmaja-Korjonen K (2007) Atlas of Subfossil Cladocera from Central and Northern Europe. wyd. Towarzystwo Przyjaciół Dolnej Wisły, Świecie

ter Braak CJF, Prentice IC (1988) A theory of gradient analysis. Adv Ecol Res 18:271-317

ter Braak CJF, Šmilauer P (2002) CANOCO reference manual and CanoDraw for Window's User's guide: software for canonical community ordination (Version 4.5). Microcomputer Power, Ithaca, NY, USA

Walker DA (2000) Hierarchical subdivision of Arctic tundra based on vegetation response to climate, parent material, and topography. Glob Chang Biol 6:19-34

Wetterich S, Schirrmeister L, Meyer H, Viehberg FA, Mackensen A (2008) Arctic freshwater ostracods from modern periglacial environment in the Lena River Delta (Siberian Arctic, Russia): geochemical applications for palaeoenvironmental reconstructions. J Paleolimnol 39:427-449 